\title{
NUMERICAL MODELING OF SINGLE-STOREY PRECAST FRAME'S PINNED CONNECTIONS WITH A SPECIAL DAMPER
}

\author{
C. Soydan ${ }^{1}$, E. Yüksel ${ }^{2}$, and E. İrtem ${ }^{3}$ \\ ${ }^{1}$ Namık Kemal University \\ Namık Kemal University, Department of Civil Engineering, Tekirdağ, Turkey \\ e-mail: csoydan@nku.edu.tr \\ ${ }^{2}$ İstanbul Technical University \\ İstanbul Technical University Faculty of Civil Engineering, İstanbul, Turkey \\ yukselerc@itu.edu.tr \\ ${ }^{3}$ Balıkesir University \\ Balıkesir University, Department of Civil Engineering, Balıkesir, Turkey \\ eirtem@balikesir.edu.tr
}

Keywords: Single Storey Precast Frames, Pinned Beam-Column Connections, Numerical Modeling, Lead Extrusion Damper.

\begin{abstract}
Single-storey precast frames with pinned beam-column connections are widely used in Turkey. This type of precast structures had suffered extensive damages during the recent major earthquakes (Ceyhan (1998), Kocaeli (1999), Duzce (1999)). The damages had been generally concentrated on the pinned connections as failure of dowels or at the column bases as large plastic deformations.

A special lead extrusion damper (LED) has been developed in an ongoing PhD study in Istanbul Technical University. The damper is going to be installed into the pinned connection regions of the single storey precast frames.

Nearly half scaled specimens representing existing features of precast frames are planned to be tested on the shake table. Prior the experimental work, an extensive blind prediction study has been carried out through the nonlinear dynamic time history analyses of the numerical models which are representing the specimens with and without damper. The numerical models are generated with Seismostruct. The comparison of the structural behaviors between the bare frame and the frame with LED has been discussed. Although the relative drifts of the precast frame has been significantly reduced, the observed base shear demand moderately increased by the installation of the LED.
\end{abstract}




\section{INTRODUCTION}

Single storey precast frames are adopted worldwide especially as industrial buildings. In Turkey, simple dry pinned connections are widely used for beam-column joints of industrial buildings. Pinned beam-column connections of single storey precast frames have usually two dowels at the top of the columns. These dowels are installed into the beams where the holes are released at the appropriate places during production process of the beams. These holes are located at the end regions and filled with non-shrinking mortar to actualize the adherence anchorage of the dowels. Generally, the dowels are not bolted if the anchorage length of the dowels through the precast elements is sufficient.

The structures consisting of single storey precast frames had suffered extensive damages during the recent major earthquakes (Ceyhan (1998), Kocaeli (1999), Duzce (1999)) in Turkey. These damages had been generally concentrated on the pinned connections as failure of dowels or at the column bases as large plastic deformations. The seismic design of precast structures with pinned beam-column connections is based on formation of plastic deformations within the critical regions of the columns through column bases. The energy dissipation actualized in the prescribed regions in the columns while the connections remain in the elastic range.

A special lead extrusion damper (LED) has been developed in an ongoing $\mathrm{PhD}$ study in Istanbul Technical University. The damper is placed into the pinned connection regions of the single storey precast frames. The main purpose of this application is to reduce the top displacement of the precast frames and the base rotation of the columns so decreasing the relative drifts of precast frames and the effect of geometric nonlinearity on columns.

Nearly half scaled specimens representing one half of a precast frame with a pinned beamcolumn connection are going to be tested on the shake table. A blind prediction study has been carried out with the numerical models representing the precast specimens. The nonlinear dynamic time history analyses are executed for the bare frame and the frame with LED using Seismostruct which is a computer program for the static and dynamic nonlinear analysis of framed structures. The comparison of the structural behaviors between the bare frame and the frame with LED has been discussed.

\section{LEAD EXTRUSION DAMPERS}

LED utilizes the hysteretic energy dissipation properties of lead. The process of extrusion consists of forcing a material through a hole or an orifice, thereby altering its shape [1]. The pressure applied to the ram forces the lead to flow through the orifice, producing a microstructure of elongated grains containing many crystal lattice defects. A proportion of the energy required to extrude the lead appears immediately as heat, but some is stored in the deformed lead and is the primary driving force for three interrelated processes (recovery, recrystallization and grain growth) which tend to restore the lead to its original condition $[2,3]$ (Figure 1).

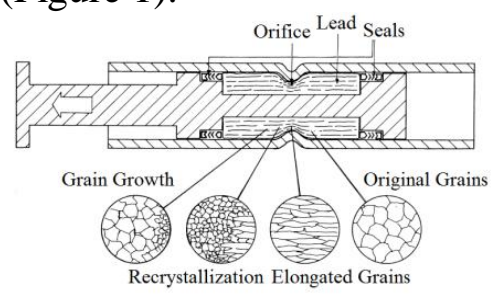

(a)

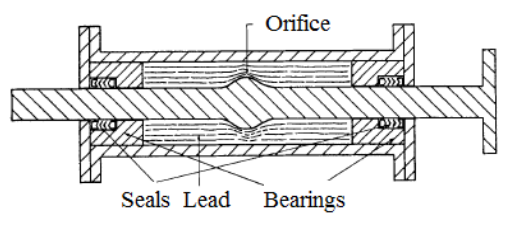

(b)

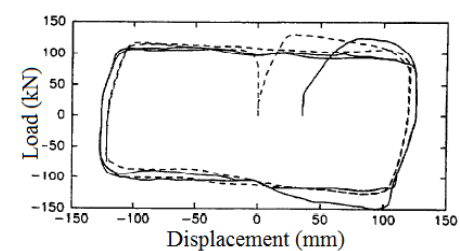

(c)

Figure 1: LED; (a) Longitudinal section of a constricted tube LED showing the changes in microstructure of the lead [4] (b) Longitudinal section of a bulged shaft LED [5] (c) Hysteresis loops of LED [6]. 
A special lead extrusion damper (LED) has been developed in an ongoing PhD study in Istanbul Technical University. A bulged shaft LED design is adopted in this study (Figure 2). There is a sphere shaped bulge at the center of the shaft. The space between the elements is filled with lead. The diameter of the shaft and the bulge are $32 \mathrm{~mm}$ and $44 \mathrm{~mm}$, respectively. The internal diameter of the tube is $60 \mathrm{~mm}$ and the thickness of the tube is $12 \mathrm{~mm}$. The gap between the bulge and the tube is $8 \mathrm{~mm}$. The displacement capacity of the LED is $\pm 33 \mathrm{~mm}$.

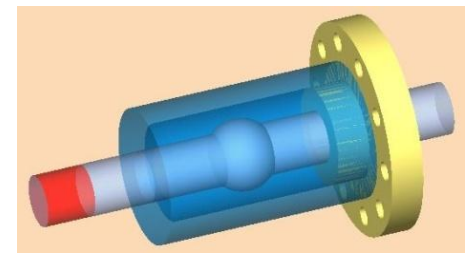

Figure 2: 3D demonstration of LED.

\section{LITERATURE REVIEW}

The dowel mechanism was investigated and the recommendations for the calculation of dowel strength both under monotonic and cyclic loading conditions were proposed by Vintzeleou and Tassios $(1985,1987)$ [7, 8]. The shear resistance of the connections between precast elements under monotonic and cyclic loading was investigated by Tsoukantas and Tassios (1989) [9] and design values for the shear resistance of each connection were proposed.

A friction damper was inserted in the region of beam-to-column connections of a precast industrial building to provide additional damping to the structure by Martinelli and Mulas (2009) [10]. A prototype building was designed for a medium-to-high seismic risk. The device efficiency in modifying favorably the structural behavior was analyzed by comparing the seismic response of the bare and redesigned frame to twelve accelerograms having a PGA equal to the design value. A non-critical shear increase in the zones where the device was inserted was found, largely counteracted by the reduction in extreme values for top displacement, bending moment at the column base and amount of energy dissipated in the hysteresis of materials.

The strength and deformation capacity of the pinned beam-to column connection with one dowel located at the center of the column were investigated with monotonic and cyclic tests by Kramar et al. (2010) [11] where rotations were controlled by different flexural strength of columns. It was stated that the strength and deformation capacity of the connections both for the monotonic and cyclic loading were much larger than determined according to the existing analytical expressions.

The monotonic test was carried out up to the failure of the specimen to obtain the loaddisplacement curve of the dowel connection and an analytical model of the beam-column pin connection for weak mechanism was presented by Capozzi et al. (2012) [12].

The cyclic response of single centrically, single eccentrically and double eccentrically located dowel connections was experimentally investigated and the parameters which control the type of the failure were identified by Fischinger et al. (2012) [13]. A numerical non-linear macro-model which was included in SAP2000 via multilinear plastic nonlinear type uniaxial link element (pivot type) of the investigated connections was identified.

The numerical model for beam-column dowel connection behavior was proposed and the results from the analytical research for different type of beam-column connections under seismic action were presented by Apatolska et al. (2012) [14]. The nonlinear behavior of con- 
nection was modeled by using multi-linear pivot hysteretic plastic property in SAP2000. Nonlinear time history analyses were conducted with the constructed analytical model.

Precast beam and column elements connected with dowels were tested under monotonic and cyclic pure shear loading by Psycharis and Mouzakis (2012a) [15]. The research was focused on several design aspects as the shear ductility capacity of the connections and the effect of various parameters on their strength. The diameter and the number of the dowels, the distances of the dowels from the edges of the beam in the longitudinal and transverse direction, and the strength of the grouts in the ducts were examined as parameters. The strength of the connection was lower in the pull direction than that in the push direction for both monotonic and cyclic loading due to the early spalling of the concrete for small ratios of "the distance of the dowels from the edge of the beam in the longitudinal direction/the diameter of the dowel". The cyclic response of the connections showed lower resistance, less than half of the monotonic response. Significant values of shear ductility could be achieved by dry pinned joints if the concrete cover of the dowels had sufficient thickness for cyclic loading. A formula was proposed for the calculation of the shear strength of pinned connections.

The behavior of precast frames with pinned connections was investigated with shaking table tests by Psycharis and Mouzakis (2012b) [16]. The frames that had different sections of columns having varying longitudinal reinforcement ratios were adopted in the tests while beam sections remain the same. The frame columns were designed as flexible and weak (under-reinforced) in which large rotations were induced at the joints, flexible and strong (overreinforced) in which significant rotations and shear forces were induced at the joints and stiff and strong (over-reinforced) in which small rotations and large shear forces induced at the joints within the frame. The base motions were applied in the plane of the frame was piecewise increasing up to the point that significant damage observed. The results were compared with those of connections of the same geometry subjected to pure shear cyclic loading.

\section{DESCRIPTION OF THE SPECIMENS}

The specimens consist of a beam attached to a column with a doweled connection on the corbel that is located at the top of the column. Nearly one half of the single storey one bay frame was modeled due to the $2.35 \mathrm{~m} \times 2.35 \mathrm{~m}$ plan dimensions of the shake table, the capacity of the hydraulic jack and the laboratory facilities (Figure 3 ).

The dimensions of the column cross section are $30 \mathrm{~cm} \times 30 \mathrm{~cm}$ and the height of the column is $2.28 \mathrm{~m}$. The length of the column inside the foundation socket is $60 \mathrm{~cm}$. The areal reinforcement ratio of longitudinal bars for the column is 1\% (8Ø12) (Figure 4) which also represents the minimum (lower) limit of longitudinal reinforcement for columns in Turkish Earthquake Code 2007 [17]. The transverse reinforcement for the column is located with $7.5 \mathrm{~cm}$ and $15.0 \mathrm{~cm}$ spacing inside and outside of the plastic hinge region respectively.

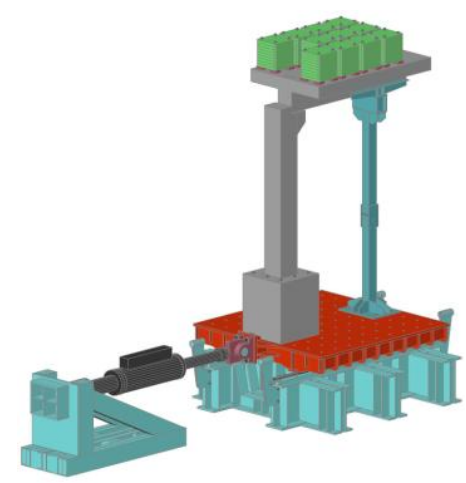

Figure 3: 3D demonstration of experimental setup. 
The dimension of the corbel can be seen in Figure 5 and 6. The beam is located on the corbel with a $2.5 \mathrm{~cm}$ gap between the beam and the column face.

The beam has a constant T-shape cross section with a $1.25 \mathrm{~m}$ slab width (Figure 4). This slab width is needed for the installation of 3.5 tons additional mass on the top of the specimen. The beam is located on the column corbel with a rubber pad of $1 \mathrm{~cm}$ thickness and $18.5 \mathrm{~cm} \times 21 \mathrm{~cm}$ plan dimensions between the column and the beam. Two M14 dowels are used through the pinned connection of precast frame. The distance of the axes of the dowels is $10 \mathrm{~cm}$ and the distance of the axes of the dowels from the beam edge (perpendicular to the loading direction) is $7.5 \mathrm{~cm}(5.4 \varnothing)$. On the other hand, the distance of the axes of the dowels from the beam edge in the loading direction is $11.25 \mathrm{~cm}(8.0 \varnothing)$ (Figure 5).

The dowels are inserted in the holes of section $60 \mathrm{~mm} \times 40 \mathrm{~mm}$ that are released at the end region of the beam. These holes are filled with non-shrinking mortar to actualize the adherence anchorage of the dowels in practice. The dowels are surrounded with six horizontal Ushape hoops at connection region and these hoops continue for a length of $70 \mathrm{~cm}$ from the beginning of the beam. The spacing of the transverse reinforcement is $7.5 \mathrm{~cm}$ in the same region and $8.0 \mathrm{~cm}$ in the rest of the beam. Total length of the beam is $2.05 \mathrm{~m}$.

The height of the specimens is $2.64 \mathrm{~m}$ from the top of the foundation socket. The total height of the specimen including the additional mass and the foundation socket is $3.865 \mathrm{~m}$. The foundation sockets are fixed to the shake table (Figure 6).

The class of concrete and the grade of reinforcing steel that is used for the specimens are C30 and S420, respectively.

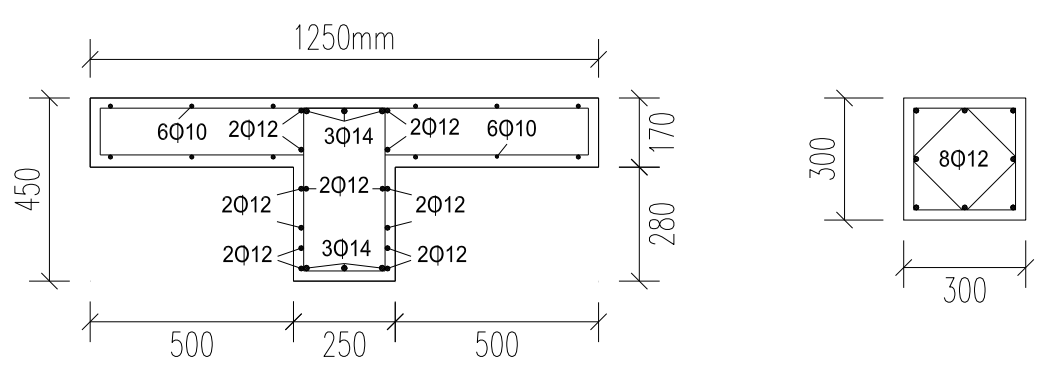

Figure 4: Sections of beam and column.
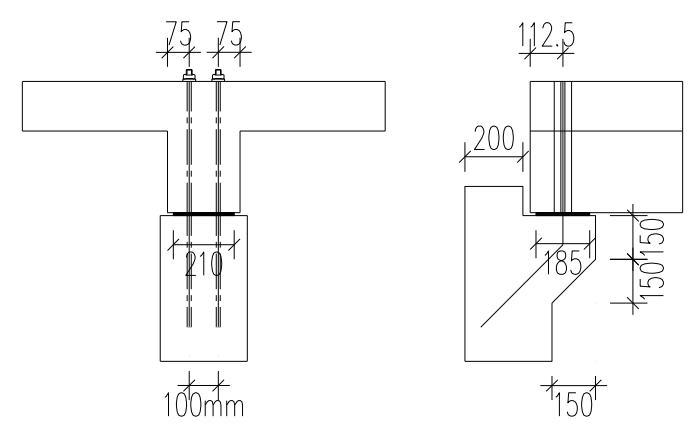

Figure 5: Dimensions of connection region. 

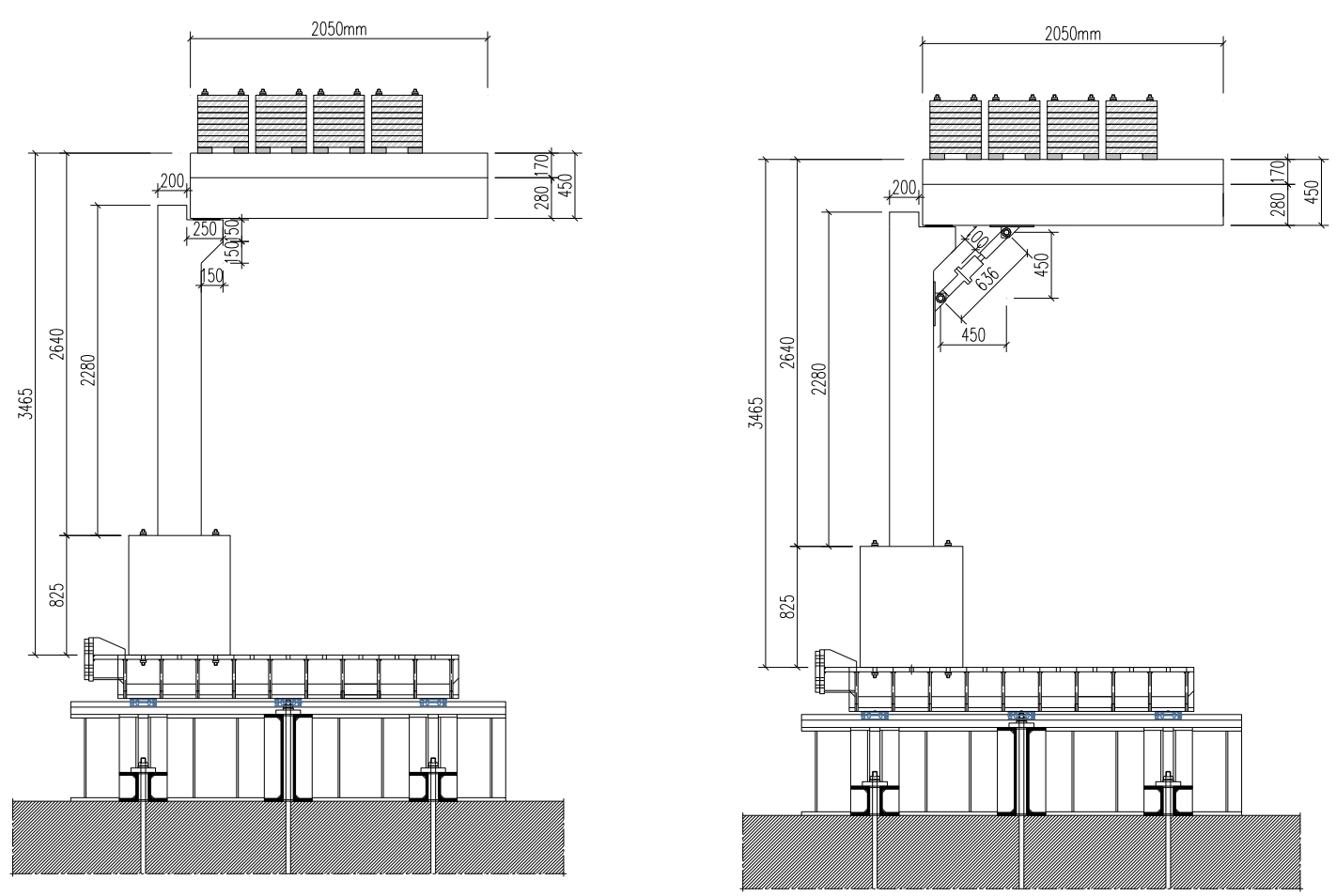

Figure 6: Pinned beam-column connections (bare and with LED)

\section{ANALYTICAL MODEL}

A plane frame model is created to represent the aforementioned specimen. Seismostruct [18] is adopted in modeling process and also in static and dynamic analysis of the constructed model. Seismostruct is a finite element package capable of predicting the large displacement behavior of space frames under static or dynamic loading, taking into account both geometric nonlinearities and material inelasticity.

The column has a square cross-section with dimensions $30 \mathrm{~cm} \times 30 \mathrm{~cm}$ and is designed with C30 class of concrete. The beam is designed with T-shape with $45 \mathrm{~cm}$ high and $25 / 125 \mathrm{~cm}$ wide with the same class of concrete (Figure 4). The grade of transverse and longitudinal reinforcement is S420 that is used for the column and the beam. The column height and the span of the beam are $2.5 \mathrm{~m}$ and $1.625 \mathrm{~m}$ respectively.

The column is modeled with an inelastic plastic hinge frame element that exists in Seismostruct. This element features a distributed inelasticity forced-based formulation but concentrates such inelasticity within a fixed length of element. The formation of plastic deformations is expected within the critical regions of the columns through column bases. The length of plastic hinge is determined from Equation 1 [19].

$$
l_{p}=0.081+0.022 f_{y} d_{b}
$$

In Equation $1 l_{p}, l, f_{y}$ and $d_{b}$ expresses the plastic hinge length, the length of the relevant element, the yield strength of longitudinal reinforcement and the diameter of longitudinal reinforcement respectively.

The core and the cover concrete behavior are modeled via nonlinear concrete model. This is a uniaxial nonlinear constant confinement model, initially programmed by Madas (1993) [20], that follows the constitutive relationship proposed by Mander et al. (1988) [21] and the cylic rules proposed by Martinez-Rueda and Elnashai (1997) [22]. The confinement effects 
provided by the lateral transverse reinforcement are incorporated through the rules proposed by Mander et al. [1988] whereby constant confining pressure is assumed throughout the entire stress-strain range [18]. The confinement factor is taken into account due to quality and quantity of longitudinal and transverse reinforcement of the column.

The behavior of the longitudinal reinforcement is modeled by bilinear steel model. This is a uniaxial bilinear stress-strain model with kinematic strain hardening, whereby the elastic range remains constant throughout the various loading stages, and the kinematic hardening rule for the yield surface is assumed as a linear function of the increment of plastic strain [18].

The beam section is overdesigned to realize the expected plastic deformation within the column base or as the failure of dowels. Therefore the beam is modeled with an elastic frame element. The additional masses on the beam slab are modeled with relatively stiff elastic frame elements where distributed mass is assigned. Similarly, the elements which connect the additional masses with beam are modeled with relatively stiff elastic frame elements but no mass is assigned to these elements (Figure 7).

The elements in the corbel region of column and the initial region of beam, which are perpendicular (orthogonal) to the axes of column and beam respectively (Figure 7), are modeled with elastic frame elements that are relatively stiff. All elements, except the additional mass representing and connecting elements, are assigned with their own masses.

The rubber pad is located between the beam and the column and modeled with 11 linear springs which are connected in parallel (Figure 7). These springs are only compression members (the springs in green) except the central one. The central spring is modeled as a tension and compression member (the spring in blue) that has the tension characteristics due to the dowels and the compression characteristics due to the rubber pad. The tension and compression stiffness of the springs are obtained with elongation stiffness of the related members. The central spring also has a lateral link element characteristic (the spring in magenta) to represent the shear resistance and shear ductility capacity of the connection.

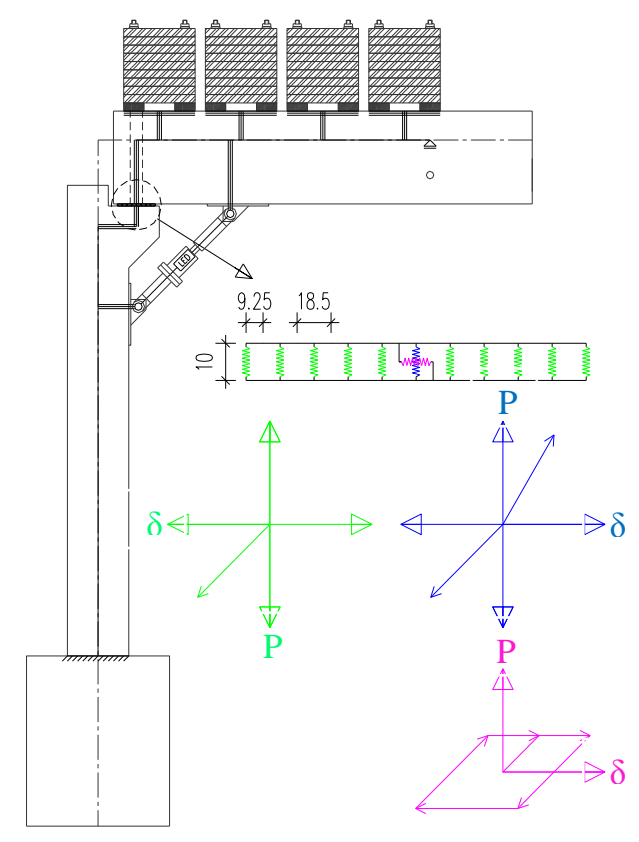

Figure 7: Analytical model of pinned beam-column connections 
The stiffness of the uniaxial springs in compression is related to modulus of elasticity $(100 \mathrm{MPa})$, area $(185 \mathrm{~mm} \times 210 \mathrm{~mm})$ and thickness $(10 \mathrm{~mm})$ of the rubber pad. Similarly the stiffness of the uniaxial spring in tension is related to the elasticity modulus (200000 MPa), the area (2M14) and the length of the dowels $(10 \mathrm{~mm})$.

The shear resistance of pinned connections to be used in the seismic design of precast structures is obtained by Equation 2 which is proposed by Psycharis and Mouzakis (2012a) [15].

$$
\begin{gathered}
R_{d}=\frac{C_{0}}{\gamma_{R}} n D^{2} \sqrt{f_{c d} f_{y d}} \text { for } d / D>6.00 \\
R_{d}=\frac{C_{0}}{\gamma_{R}}\left(0.25 \frac{d}{D}-0.50\right) n D^{2} \sqrt{f_{c d} f_{y d}} \text { for } 4.00 \leq d / D \leq 6.00
\end{gathered}
$$

In Equation 2 and 3 the $d$ and $D$ represents the distance of the axis of the dowels from the beam edge in the loading direction and the diameter of the dowels respectively. $C_{0}$ is a coefficient varying from 0.90 and 1.10 depending on the magnitude of expected joint rotations. If large joint rotations may occur (flexible columns) a value of 0.90-0.95 is suggested. The maximum value of $C_{0}$ is 1.10 for practically zero joint rotations. $\gamma_{R}$ represents a general safety factor for the uncertainties in the experimental procedure and the limited number of experimental data used in the derivation of these equations. It is suggested that $\gamma_{R} \approx 1.30$. The $n, f_{c d}$ and $f_{y d}$ represent the number of the dowels, the compression design value of concrete and the yield design value of the dowel, respectively [15].

In Psycharis and Mouzakis (2012a) [15] the shear ductility capacity of the connections was calculated from their cyclic response, considering as ultimate displacement the one that corresponds to $20 \%$ drop in the strength. If the distance of the dowels from the beam edge was large enough $(\mathrm{d} / \mathrm{D} \geq 6)$ quite satisfactory values of shear ductility capacity were attained, ranging from 4 to 6 .

In this study Equation 2 is adopted because $d / D$ is approximately 8 and the shear resistance is calculated as $24 \mathrm{kN}$ for the considered connection. For the same reason the expected shear ductility capacity is between 4 and 6 . The displacement value of maximum shear strength of the connections is read as approximately $5 \mathrm{~mm}$ from the test results that are presented in Psycharis and Mouzakis (2012a) [15]. Because of a nearly half-scaled specimen examined in this study, the displacement that is corresponding to the maximum shear strength of the connection is accepted as $2.5 \mathrm{~mm}$. The ultimate displacement value can be obtained as $10 \mathrm{~mm}$ with the consideration of the shear ductility capacity is 4 (the lower limit for shear ductility capacity).

The lateral link element characteristic of the central spring is modeled via bilinear kinematic curve. This is a kinematic-hardening bilinear symmetrical curve frequently employed to model idealized elastic-plastic behavior [18]. Three parameters need to be defined in order to fully characterize this response curve. These are initial stiffness $\left(\mathrm{K}_{\mathrm{o}}\right)$, yield force $\left(\mathrm{F}_{\mathrm{y}}\right)$ and post-yield hardening ratio (r) (Figure 8). The initial stiffness and yield force are considered as $9600 \mathrm{kN} / \mathrm{m}$ and $24 \mathrm{kN}$ respectively. The post yield hardening ratio is adopted as 0 .

The LED is also represented with the aforementioned link element. The initial stiffness, the yield strength and the post-yield hardening ratio is considered as $350000 \mathrm{kN} / \mathrm{m}, 75 \mathrm{kN}$ and 0.0003 respectively for the LED. The elements which connect the LED to column and beam elements are modeled with relatively stiff elastic frame elements but no mass is assigned to these elements (Figure 8). 


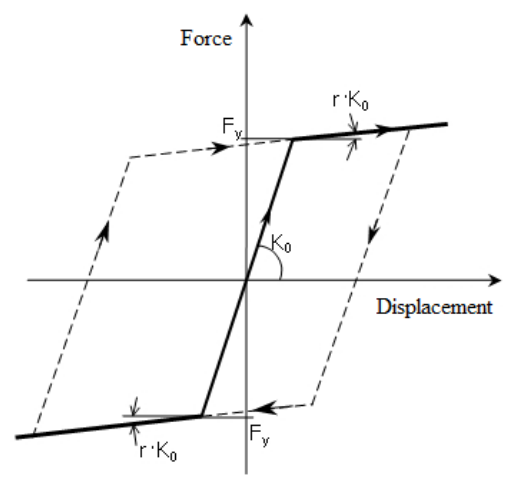

Figure 8: Kinematic-hardening bilinear symmetrical curve [18].

\section{GROUND MOTIONS}

The nonlinear dynamic time history analyses are executed with the bare frame and the frame with LED using Seismostruct which is a computer program for the static and dynamic nonlinear analysis of framed structures. Seven near fault and seven far fault type ground motions are considered in nonlinear dynamic time history analyses. The accelerograms used in this study are selected from the PEER NGA database [23].

The acceleration response spectra of the original accelerograms and the arithmetic mean of these accelerograms for 5\% damping are given in Figure 9. The response spectrum for the $2^{\text {nd }}$ earthquake zone (where effective acceleration coefficient is 0.3 ) and the ground soil type Z3 (which represents the firm soil with spectrum characteristic periods of $0.15 \mathrm{~s}$ and $0.60 \mathrm{~s}$ ) that is defined in Turkish Earthquake Code [17] is also presented in Figure 9. The ground motions and the related station name which are used in this study are listed in Table 1.

\begin{tabular}{|c|c|c|c|c|c|c|c|}
\hline $\begin{array}{l}\text { Fault } \\
\text { Type }\end{array}$ & Station Name & Earthquake & Year & Magnitude & Component & $\begin{array}{c}\text { PGA } \\
(\mathrm{g})\end{array}$ & $\begin{array}{c}\text { PGV } \\
(\mathrm{cm} / \mathrm{s})\end{array}$ \\
\hline \multirow{7}{*}{$\tilde{\Xi}^{ \pm}$} & El Cen. Array \#4 & Imp. Valley & 1979 & 6.53 & 140 & 0.485 & 37.39 \\
\hline & TCU076 & Chi-Chi & 1999 & 7.62 & $\mathrm{~N}$ & 0.416 & 64.20 \\
\hline & El Cen. Array \#5 & Imp. Valley & 1979 & 6.53 & 140 & 0.519 & 46.87 \\
\hline & Sarat. Aloha Ave & Loma Prieta & 1989 & 6.93 & 000 & 0.512 & 41.15 \\
\hline & S5051 & Super. Hills & 1987 & 6.22 & 315 & 0.377 & 43.88 \\
\hline & LA Dam & Northridge & 1994 & 6.69 & 334 & 0.349 & 50.81 \\
\hline & Erzincan & Erzincan & 1992 & 6.69 & East-West & 0.496 & 64.28 \\
\hline \multirow{7}{*}{ 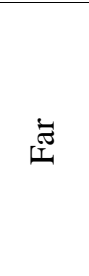 } & Saticoy & Northridge & 1994 & 6.69 & 090 & 0.368 & 28.88 \\
\hline & TCU067 & Chi-Chi & 1999 & 7.62 & $\mathrm{~N}$ & 0.325 & 66.69 \\
\hline & Delta & Imp. Valley & 1979 & 6.53 & 352 & 0.351 & 33.00 \\
\hline & Sun Vall.-Roscoe & Northridge & 1994 & 6.69 & 090 & 0.444 & 38.21 \\
\hline & Poe Road & Super. Hills-02 & 1987 & 6.54 & 360 & 0.300 & 32.78 \\
\hline & Holl. Diff. Array & Loma Prieta & 1989 & 6.93 & 165 & 0.269 & 43.86 \\
\hline & TCU079 & Chi-Chi & 1999 & 7.62 & $\mathrm{~N}$ & 0.393 & 48.82 \\
\hline
\end{tabular}

Table 1: Main characteristics of the accelerograms. 

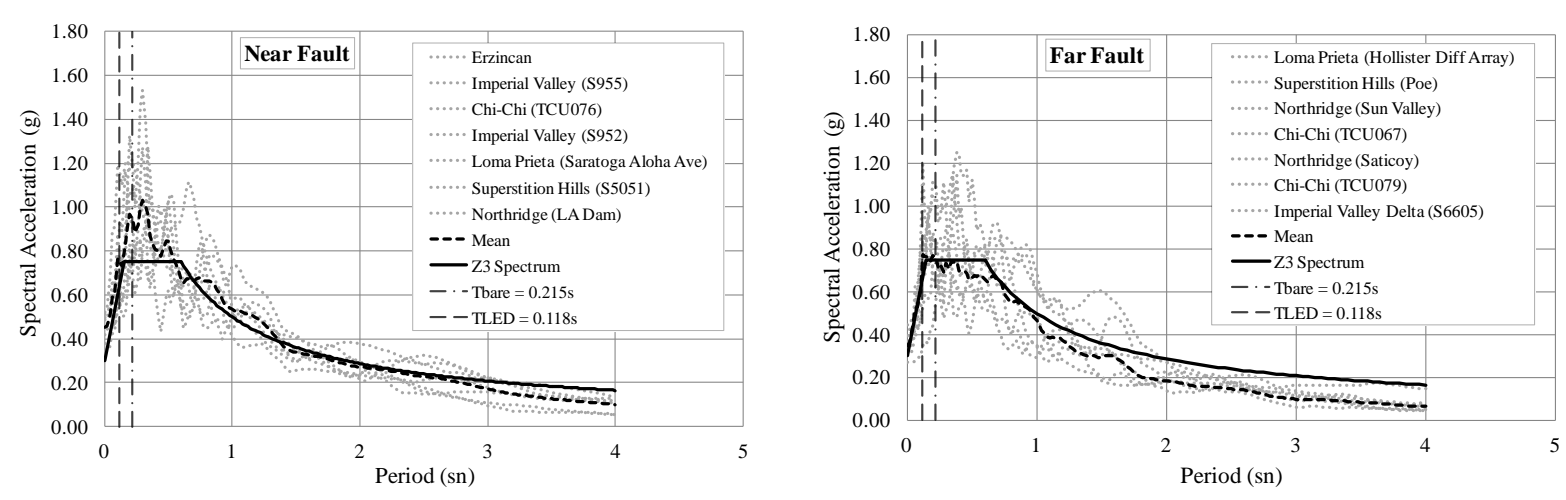

Figure 9: Response spectrum for near and far fault type ground motions

\section{NUMERICAL ANALYSIS}

The nonlinear dynamic time history analyses are executed with the bare frame and the frame with LED using Seismostruct which is a computer program for the static and dynamic nonlinear analysis of framed structures.

The base shear vs. top displacement relationship of the specimen, the moment vs. rotation relationship of the specimen column base section, the lateral force vs. slip of the dowels and the axial force vs. axial displacement of the LED are monitored through these analyses for near fault and far fault type ground motions.

The Newmark time integration method $(\beta=0.25, \gamma=0.50)$ is adopted for all nonlinear time-history analyses, with a time step equal to the related ground motion acceleration record time step (0.005 s or $0.01 \mathrm{~s})$. A Rayleigh type viscous damping is assumed, with the damping matrix proportional to the mass and initial stiffness matrix. A damping ratio of $5.0 \%$ is imposed for the first two modes of the model where $T_{1}$ and $T_{2}$ are $0.215 \mathrm{~s}$ and $0.027 \mathrm{~s}$ for the bare specimen and $0.118 \mathrm{~s}$ and $0.015 \mathrm{~s}$ for the specimen with LED, respectively.

\subsection{Base shear vs. top displacement of the specimens}

The base shear vs. top displacement relationships for the bare specimen and the specimen with LED that are obtained from dynamic time history analyses are presented in Figure 10 and Figure 11. It can be seen that the lateral stiffness of the specimen is increasing with the installation of the LED. The top displacement and plastic deformations of the specimen are decreasing both for near and far fault type ground motions.

The maximum base shear for the considered near and far fault type ground motions are $28.96 \mathrm{kN}$ (Imperial Valley, El Centro Array \#5) and $28.25 \mathrm{kN}$ (Northridge, Sun Valley) respectively for the bare specimen. Similarly, the maximum values of top displacement are $26 \mathrm{~mm}$ (Imperial Valley, El Centro Array \#4) and $22 \mathrm{~mm}$ (Chi-Chi, TCU067) for the near and far fault type ground motions respectively.

The base shear of the specimen with LED is increased 19\% $(34.57 \mathrm{kN}$ for Imperial Valley, El Centro Array \#5) while the top displacement is decreased 54\% (12 mm for Imperial Valley, El Centro Array \#4) for the near fault type ground motions. The increment in the base shear is obtained as $18 \%$ ( $33.30 \mathrm{kN}$ for Northridge, Sun Valley) and the decrement in the top displacement is obtained as 50\% (11 mm for Northridge, Saticoy) for the far fault type ground motions with the comparison of the maximum values. These values are presented bold in Table 2 . 

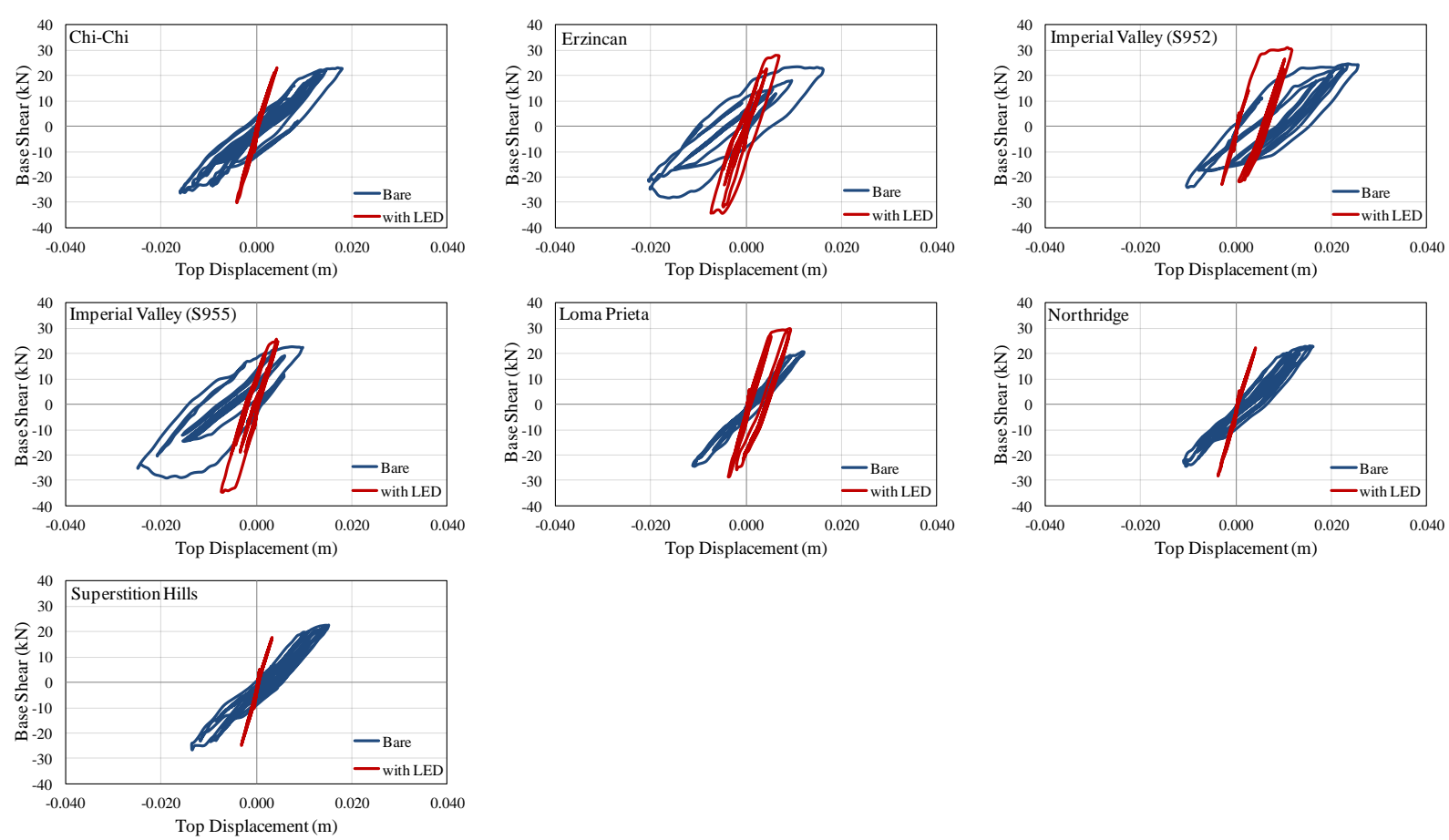

Figure 10: Base shear vs. top displacement relationships of specimen for near fault type ground motions
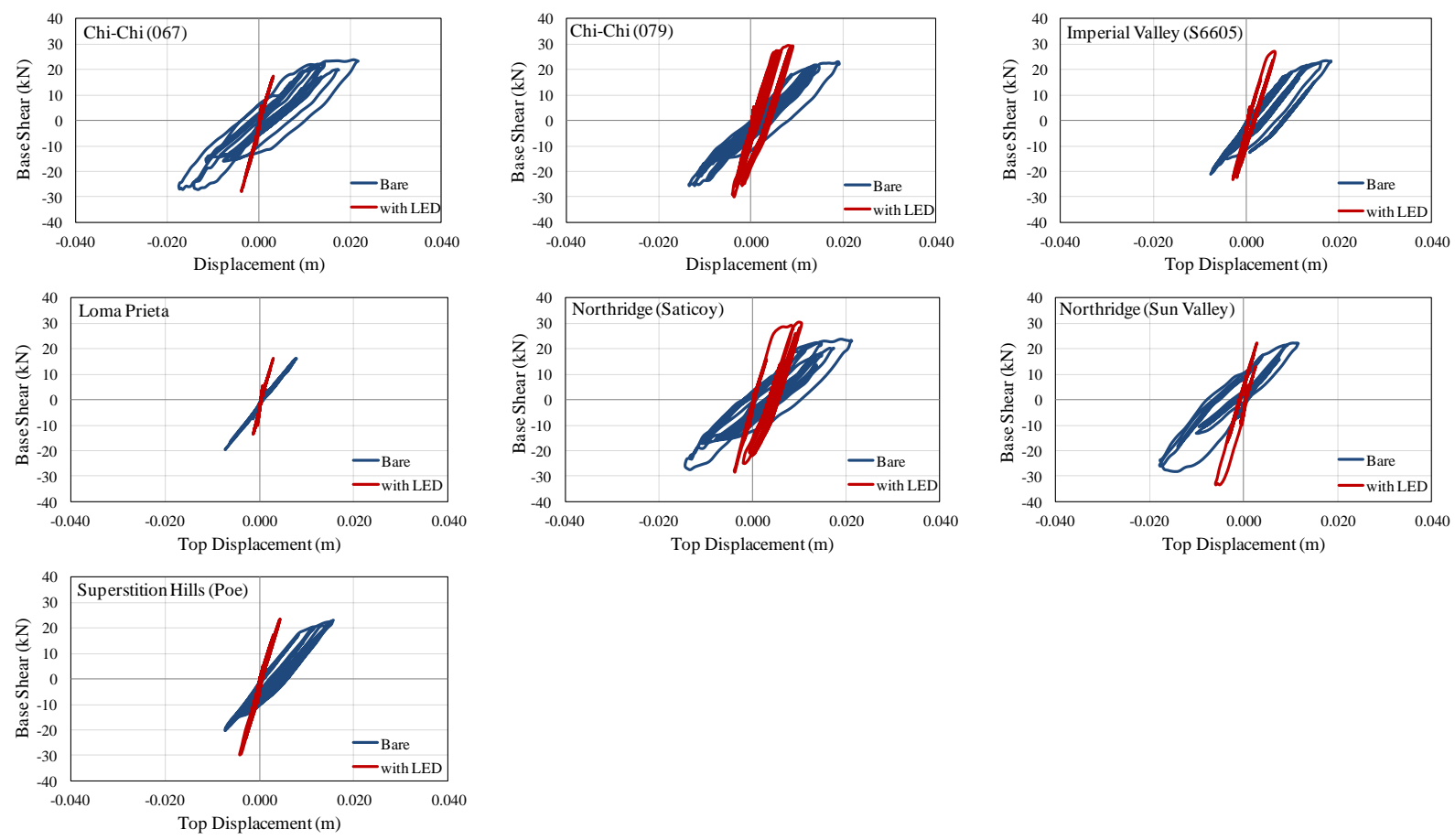

Figure 11: Base shear vs. top displacement relationships of specimen for far fault type ground motions 


\begin{tabular}{|c|c|c|c|c|c|c|}
\hline \multirow[b]{2}{*}{$\begin{array}{l}\text { Fault } \\
\text { Type }\end{array}$} & \multirow[b]{2}{*}{ Station Name } & \multirow[b]{2}{*}{ Earthquake } & \multicolumn{2}{|c|}{ Bare Specimen } & \multicolumn{2}{|c|}{ Specimen with LED } \\
\hline & & & $\begin{array}{c}\text { Base Shear } \\
(\mathrm{kN})\end{array}$ & $\begin{array}{c}\text { Top Displacement } \\
(\mathrm{mm})\end{array}$ & $\begin{array}{c}\text { Base Shear } \\
(\mathrm{kN})\end{array}$ & $\begin{array}{c}\text { Top Displacement } \\
\text { (mm) }\end{array}$ \\
\hline \multirow{7}{*}{ 苂 } & El Cen. Arr. \#4 & Imp. Valley & 24.71 & 26 & 31.09 & 12 \\
\hline & TCU076 & Chi-Chi & 26.56 & 18 & 31.14 & 4 \\
\hline & El Cen. Arr. \#5 & Imp. Valley & 28.96 & 25 & 34.57 & 7 \\
\hline & Saratoga Aloha & Loma Prieta & 24.63 & 12 & 29.71 & 9 \\
\hline & S5051 & Super. Hills & 26.82 & 15 & 25.06 & 3 \\
\hline & LA Dam & Northridge & 24.54 & 16 & 28.33 & 4 \\
\hline & Erzincan & Erzincan & 28.35 & 20 & 34.24 & 7 \\
\hline \multirow{7}{*}{ 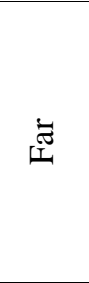 } & Saticoy & Northridge & 27.41 & 21 & 30.39 & 11 \\
\hline & TCU067 & Chi-Chi & 27.20 & 22 & 28.14 & 4 \\
\hline & Delta & Imp. Valley & 23.51 & 18 & 27.07 & 6 \\
\hline & Sun Valley & Northridge & 28.25 & 18 & 33.30 & 6 \\
\hline & Poe Road & Super. Hills & 22.82 & 15 & 29.95 & 4 \\
\hline & Holl. Diff. & Loma Prieta & 19.73 & 8 & 16.32 & 3 \\
\hline & TCU079 & Chi-Chi & 25.81 & 19 & 30.18 & 9 \\
\hline
\end{tabular}

Table 2: Top displacement and base shear of specimen.

\subsection{Moment vs. rotation of the columns}

The moment vs. rotation relationships for the column base section of the bare specimen and the specimen with LED are presented in Figure 12 and Figure 13. The moment and rotation of the column are decreasing both for near and far fault type ground motions. It can also be seen that plastic deformations are reduced for considered ground motions.

The maximum moment for the column base section are $49.55 \mathrm{kNm}$ (Imperial Valley, E1 Centro Array \#5) and $49.05 \mathrm{kNm}$ (Northridge, Sun Valley) for the near and far fault type ground motions respectively for the bare specimen. The maximum values of rotation for the same section are $0.011 \mathrm{rad}$ (Imperial Valley, El Centro Array \#4) and $0.010 \mathrm{rad}$ (Chi-Chi, TCU067) for the near and far fault type ground motions respectively.
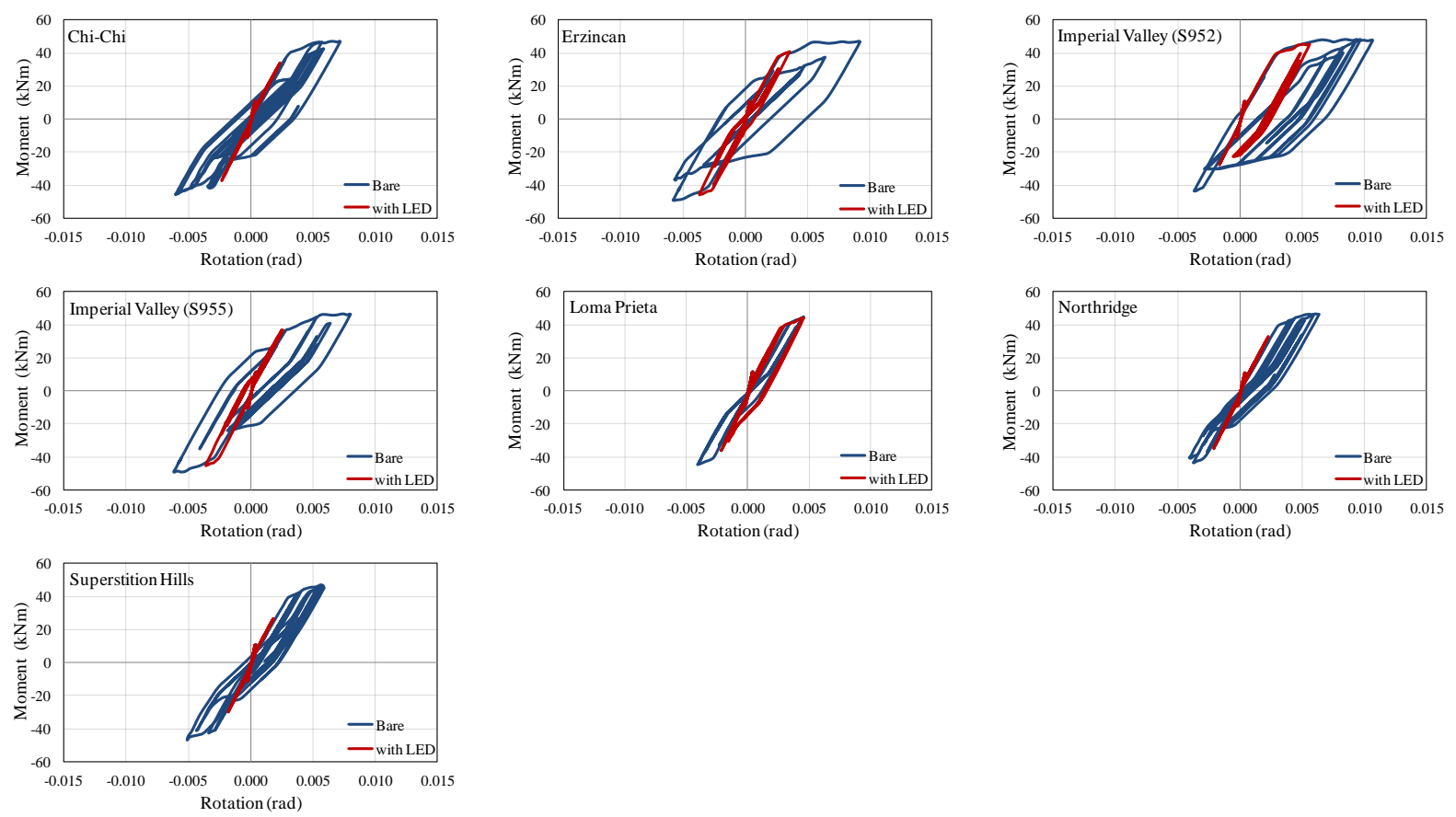

Figure 12: Moment vs. rotation relationships of column base section for near fault type ground motions 

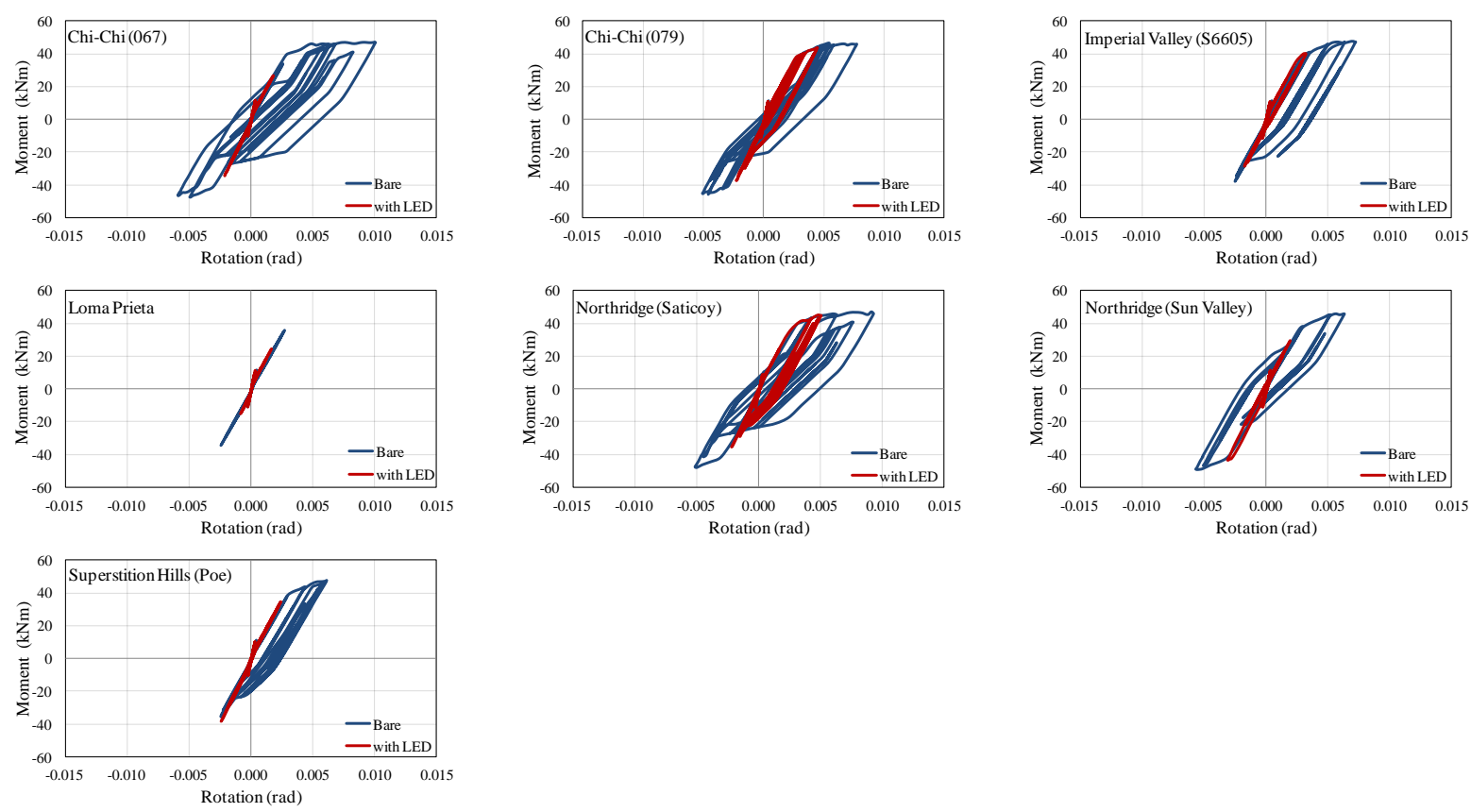

Figure 13: Moment vs. rotation relationships of column base section for far fault type ground motions

The moment of the specimen column base section with LED is decreased $7.4 \%$ (45.87 $\mathrm{kNm}$ for Erzincan) while the rotation is decreased 45\% (0.006 rad for Imperial Valley, El Centro Array \#4) for the near fault type ground motions. The decrement in the moment is obtained as 7.8\% (45.24 kNm for Northridge, Saticoy) and the decrement in the rotation is obtained as 50\% (0.005 rad for Northridge, Saticoy) for the far fault type ground motions with the comparison of the maximum values. The maximum values for the monitored relationships are presented bold in Table 3.

\begin{tabular}{|c|c|c|c|c|c|c|}
\hline \multirow[b]{2}{*}{$\begin{array}{l}\text { Fault } \\
\text { Type }\end{array}$} & \multirow[b]{2}{*}{ Station Name } & \multirow[b]{2}{*}{ Earthquake } & \multicolumn{2}{|c|}{ Bare Specimen } & \multicolumn{2}{|c|}{ Specimen with LED } \\
\hline & & & $\begin{array}{c}\text { Moment } \\
(\mathrm{kNm})\end{array}$ & Rotation (rad) & $\begin{array}{c}\text { Moment } \\
(\mathrm{kNm})\end{array}$ & Rotation (rad) \\
\hline \multirow{7}{*}{ ¿ँच } & El Cen. Arr. \#4 & Imp. Valley & 48.14 & 0.011 & 45.67 & 0.006 \\
\hline & TCU076 & Chi-Chi & 47.13 & 0.007 & 37.45 & 0.002 \\
\hline & El Cen. Arr. \#5 & Imp. Valley & 49.55 & 0.008 & 45.60 & 0.004 \\
\hline & Saratoga Aloha & Loma Prieta & 44.70 & 0.005 & 44.23 & 0.005 \\
\hline & S5051 & Super. Hills & 47.00 & 0.006 & 30.27 & 0.002 \\
\hline & LA Dam & Northridge & 46.68 & 0.006 & 34.98 & 0.002 \\
\hline & Erzincan & Erzincan & 49.14 & 0.009 & 45.87 & 0.004 \\
\hline \multirow{7}{*}{ 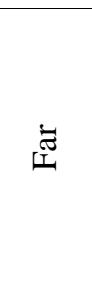 } & Saticoy & Northridge & 48.10 & 0.009 & 45.24 & 0.005 \\
\hline & TCU067 & Chi-Chi & 47.68 & 0.010 & 34.59 & 0.002 \\
\hline & Delta & Imp. Valley & 47.72 & 0.007 & 39.91 & 0.003 \\
\hline & Sun Valley & Northridge & 49.05 & 0.006 & 43.59 & 0.003 \\
\hline & Poe Road & Super. Hills & 47.07 & 0.006 & 38.24 & 0.002 \\
\hline & Holl. Diff. & Loma Prieta & 35.71 & 0.003 & 24.45 & 0.002 \\
\hline & TCU079 & Chi-Chi & 46.71 & 0.008 & 43.75 & 0.004 \\
\hline
\end{tabular}

Table 3: Moment and rotation values for the column base section of the specimen.

\subsection{The lateral force vs. slip of the dowels}

The maximum shear strength is obtained as $24 \mathrm{kN}$ and the displacement that is corresponding to the maximum shear strength of the connection is accepted as $2.5 \mathrm{~mm}$. The ultimate dis- 
placement value can be obtained as $10 \mathrm{~mm}$ with the consideration of the shear ductility capacity is 4 (the lower limit for shear ductility capacity).
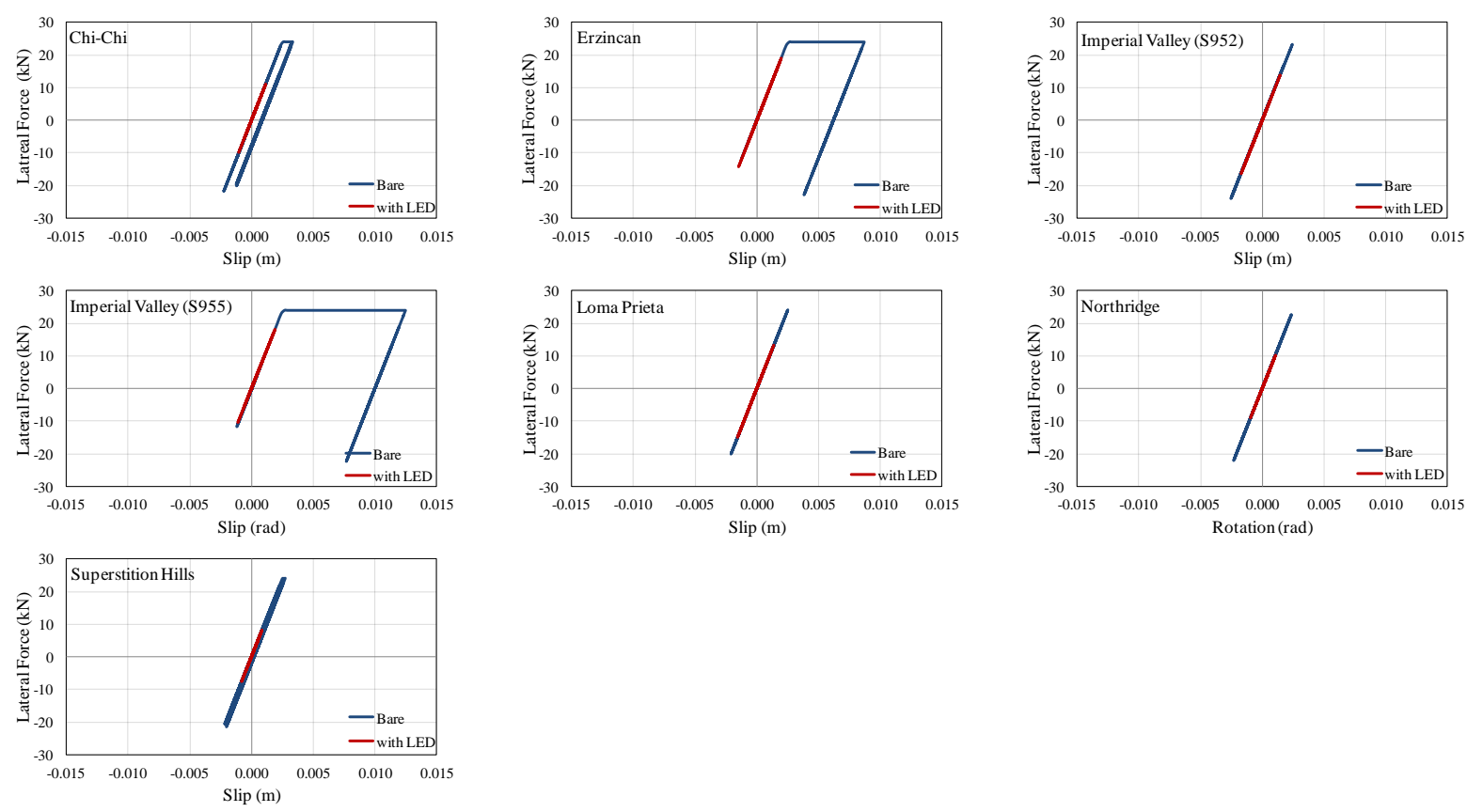

Figure 14: Lateral force vs. slip relationships of dowels for near fault type ground motions
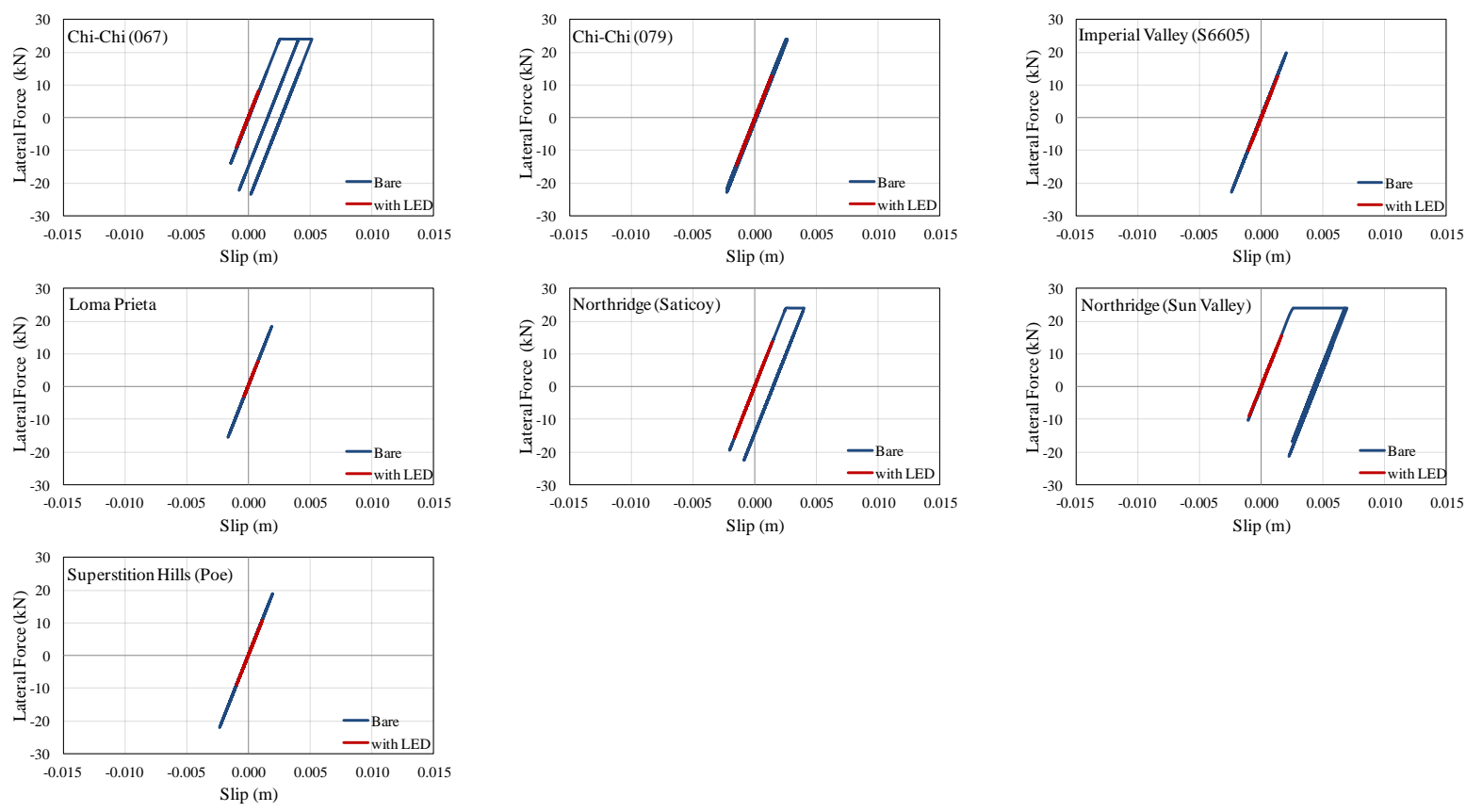

Figure 15: Lateral force vs. slip relationships of dowels for far fault type ground motions

The shear capacity of the dowels is reached and the plastic deformation of dowels is occurred in some of the ground motions that are considered in this study (Figure 14 and Figure 15). On the other hand the dowels are remained in elastic range for some of the considered ground motions. The ultimate displacement of $10 \mathrm{~mm}$ is not exceeded in most cases except Imperial Valley (S955) which is a near fault type ground motion for the bare specimen. 
After the installation of the LED the lateral force and slip are quite decreased and all of the dowels are remained in the elastic range both for the near and far fault type ground motions.

\subsection{The axial force vs. axial displacement of the LED}

The axial force-axial displacement hysteresis of the LED can be seen in Figure 16 and Figure 17. The plastic deformations in the LED are occurred in most of the ground motions except two in both the near and far fault type ground motions. These ground motions are Northridge and Superstition Hills for near fault type and Chi-Chi and Loma Prieta for far fault type.
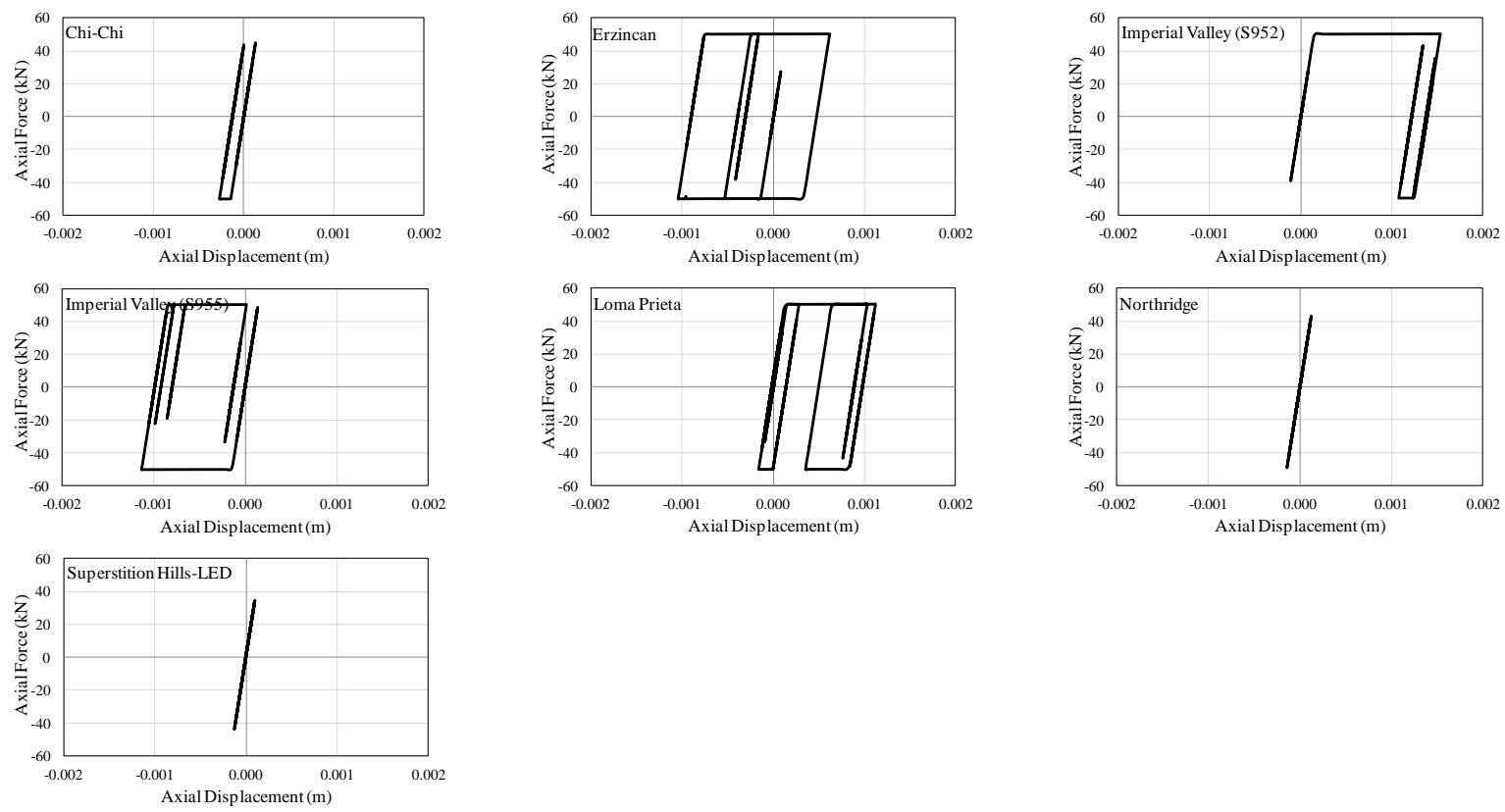

Figure 16: Axial force vs. axial displacement relationships of LED for near fault type ground motions
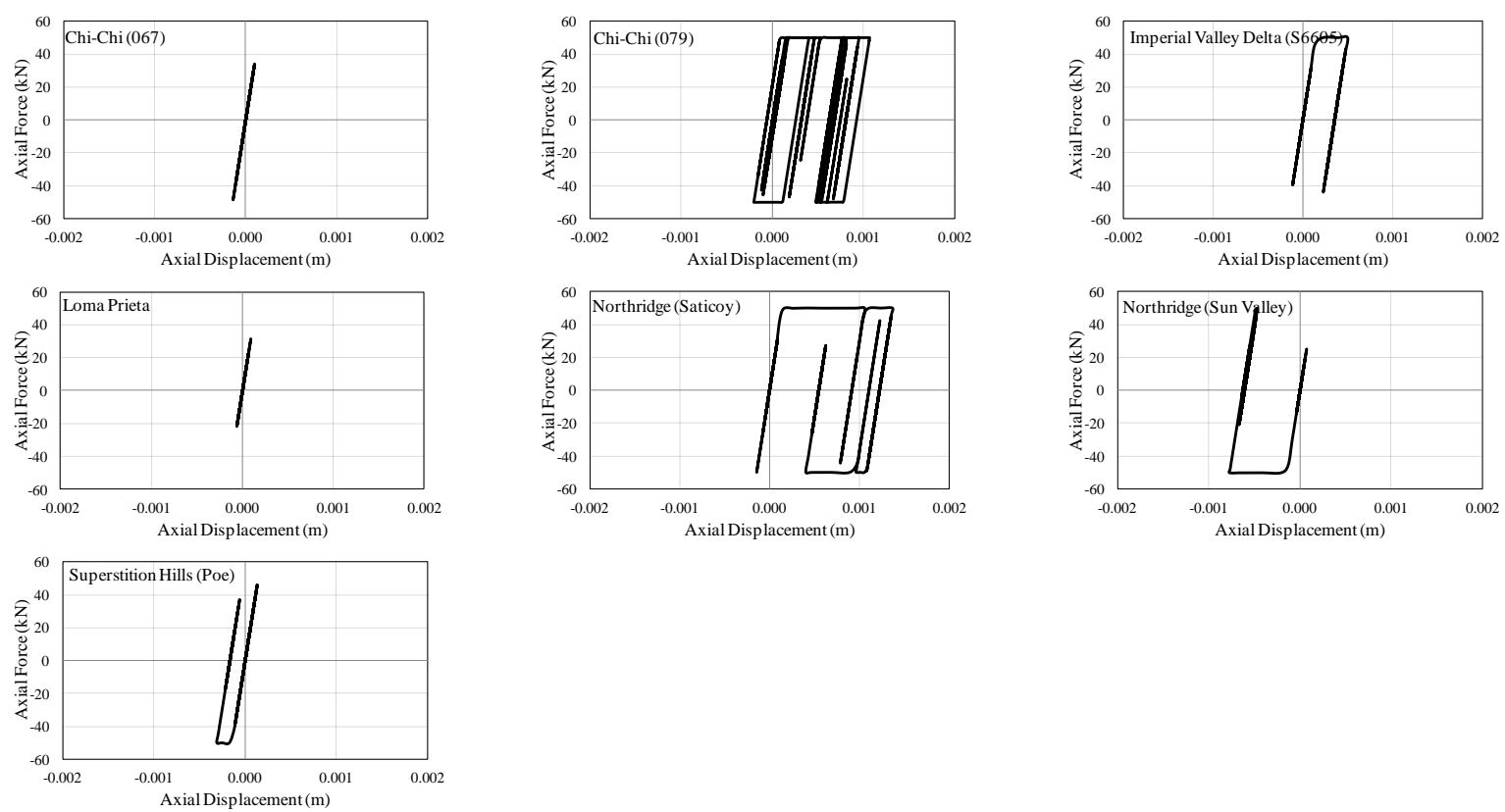

Figure 17: Axial force vs. axial displacement relationships of LED for far fault type ground motions 


\section{CONCLUSIONS}

The results of the analytical study have been evaluated for the bare frame and the frame with the LED in order to express the effectiveness the applied method for seismic retrofitting. The following conclusions could be drawn:

- The lateral stiffness of the specimen is increasing with the installation of the LED.

- The top displacement and plastic deformations of the specimen with the LED are considerably smaller than the bare specimen for near and far fault type ground motions.

- Base shear demand of the specimen with the LED are relatively bigger than the bare frame.

- At the column lower end, bending moment and rotation are decreasing both for near and far fault type ground motions with the installation of the LED.

- The dowel's inelastic behavior is exceedingly affected by the existence of the LED.

- LED is operative for near and far fault type earthquakes.

- The applied retrofitting technique is effective to reduce the in-plane seismic risk of single-story precast frames with pinned beam-column connections.

\section{REFERENCES}

[1] F. Sadek, B. Mohraz,A.W. Taylor, R.M. Chung, Passive energy dissipating devices for seismic applications. Report NISTIR 5923. Building and Fire Research Laboratory, National Institute of Standarts and Technology, Gaithersburg, Maryland, 1996.

[2] J. Wulf, J.F. Taylor, A.J. Shaler, Metallurgy for engineers. John Wiley and Sons, New York, 1956.

[3] C.E. Birchenall, Physical metallurgy. McGraw-Hill, London, 1959.

[4] W.H. Robinson, L.R. Greenbank, Properties of an extrusion energy absorber. Bulletin of the New Zealand Society for Earthquake Engineering, 8(3), 187-191, 1975.

[5] W.H. Robinson, L.R. Greenbank, Extrusion energy absorber suitable for the protection of structures during an earthquake. Earthquake Engineering \& Structural Dynamics, 4(3), 251-259, 1976.

[6] W.H. Robinson, W.J. Cousins, Recent developments in lead dampers for base isolation. Pacific Conference on Earthquake Engineering, Vol. 2. New Zealand, 1987.

[7] E.N. Vintzeleou, T.P. Tassios, Mechanics of load transfer along interfaces in reinforced concrete, prediction of shear force vs. shear displacement curves. Studie de Reserche, No.7, Corpo di Perfezionamento per le Construzioni in Cemento Amato, Italcementi Societa per Azioni (S. p:A), Bergamo, pp. 121-161, 1985.

[8] E.N. Vintzeleou, T.P. Tassios, Behavior of dowels under cyclic deformations. ACI Structural Journal, 84(1), 18-30, 1987.

[9] S.G. Tsoukantas, T.P. Tassios, Shear resistance of connections between reinforced concrete linear precast element. ACI Structural Journal, 86(3), 242-249, 1989. 
[10] P. Martinelli, M.G. Mulas, An innovative passive control technique for industrial precast frames. Engineering Structures, 32(4), 1123-1132, April 2010.

[11] M. Kramar, T. Isakovic, M. Fischinger, Experimental invesitigation of pinned beam-to-column connections in precast industrial buildings. 14th European Conference on Earthquake Engineering, Ohrid, Republic of Macedonia, 30 August-03 September, 2010.

[12] V. Capozzi, G. Magliulo, G. Manfredi, Nonlinear mechanical model of seismic behaviour of beam-column pin connections. 15th World Conference on Earthquake Engineering, Lisbon, Portugal, 24-28 September, 2012.

[13] M. Fischinger, B.Zoubek, M. Kramar, T. Isakovic, Cyclic response of dowel connections in precast structures. 15th World Conference on Earthquake Engineering, Lisbon, Portugal, 24-28 September, 2012.

[14] R. Apostolska, G. Necevska-Cvetanovska, J. Bojadziev, M. Fishinger, T. Isakovic, M. Kramar, Analytical investigations of beam-column connections in precast buildings under seismic loads. 15th World Conference on Earthquake Engineering, Lisbon, Portugal, 24-28 September, 2012.

[15] .N. Psycharis, H.P. Mouzakis, Shear resistance of pinned connections of precast members to monotonic and cyclic loading. Engineering Structures, 41:413-427, 2012a.

[16] I.N. Psycharis, H.P. Mouzakis, Assessment of the seismic design of precast frames with pinned connections from shaking table tests. Bull Earthquake Engineering, 10:1795-1817, 2012b.

[17] Turkish Earthquake Code 2007.

[18] SeismoStruct, "Computer program for static and dynamic nonlinear analysis of framed structures". (http://www.seismosoft.com).

[19] T. Paulay, M.J.N. Priestley, Seismic design of reinforced concrete and masonry buildings. John Wiley \& Sons Inc., New York, 1992.

[20] P. Madas, Advanced Modeling of Composite Frames Subjected to Earthquake Loading, $\mathrm{PhD}$ Thesis, Imperial College, University of London, London, UK, 1993.

[21] J.B. Mander, M.J.N. Priestley, R. Park, Theoretical stress-strain model for confined concrete. Journal of Structural Engineering, Vol. 114, No. 8, pp. 1804-1826, 1988.

[22] J.E. Martinez-Rueda, A.S. Elnashai, Confined concrete model under cyclic load. Materials and Structures, Vol. 30, No. 197, pp. 139-147, 1997.

[23] PEER NGA Database. Pacific earthquake engineering research center: NGA database. (http://peer.berkeley.edu/peer_ground_motion_database/) 